\title{
Microfocused Ultrasound for Facial Photorejuvenation: A Review
}

\author{
Adam J. Wulkan, MD ${ }^{1}$ Sabrina G. Fabi, MD 2,3 Jeremy B. Green, MD ${ }^{1,4}$
}

${ }^{1}$ Department of Dermatology and Cutaneous Surgery, University of

Address for correspondence Adam J. Wulkan, MD, Department of Miami, Miami, Florida

${ }^{2}$ Cosmetic Laser Dermatology, Goldman, Butterwick, Fitzpatrick, Groff and Fabi, Dermatology, San Diego, California

${ }^{3}$ Department of Dermatology, University of California San Diego, La Jolla, California

${ }^{4}$ Department of Dermatology, Skin Associates of South Florida, Coral Gables, Florida

Facial Plast Surg 2016;32:269-275.

Dermatology and Cutaneous Surgery, University of Miami, 1600 NW
10th Ave., RMSB 2023A, Miami, FL 33136 (e-mail: adamwulkan@gmail.com).

\begin{abstract}
Keywords

- Ulthera

- microfocused ultrasound

- facial rejuvenation

- noninvasive

Microfocused ultrasound is a unique technology to treat skin laxity of the brow, lower face, and the rhytides of the décolletage. Over the past several years, the efficacy and safety of this device has been well documented and its adoption widespread. By delivering focused acoustic energy, which is converted to heat, this device creates predictable and reproducible microcoagulative zones that initiate a concentrated inflammatory wound response. By targeting the deep reticular dermis and superficial muscle and fascial planes, such as the superficial musculoaponeurotic system, platysma, and pectoralis muscle fascia, this nonablative technology increases neocollagenesis and neoelastogenesis in a novel fashion, while avoiding many of the complications related to epidermal heating observed in several other nonablative devices. Although the results are not equivalent to those of a rhytidectomy, microfocused ultrasound provides an excellent noninvasive means to achieve a regenerative effect on the face, neck, and décolletage when performed in the appropriate patient population.
\end{abstract}

Historically, the ability to address face and neck skin laxity has been limited to aesthetic surgical lifting procedures. Although this remains the gold standard for treating redundant skin, patients are increasingly seeking less invasive means to ameliorate signs of facial aging. Over the past several years, there has been an emergence of noninvasive modalities in the field of facial rejuvenation to meet this increasing demand. These procedures offer decreased downtime and improved sideeffect profiles, while achieving more subtle and natural appearing results. Despite the influx of multiple skin tightening technologies, there remains a demand for attaining results approaching a surgical lift, while maintaining the advantages of the noninvasive approach. While the mechanism of action for these devices varies, their objective is essentially the same: heating the skin and subcutis to induce neocollagenesis while minimizing damage to the epidermis. ${ }^{1}$

Issue Theme Nonsurgical Facial Rejuvenation; Guest Editors, Tanja C. Fischer, MD, and Gerd G. Gauglitz, MD, MMS

\section{Evolution of Ultrasound}

Despite its widespread use for diagnostics, ultrasound technology has been employed for therapeutic purposes for several decades. In 2004, high-intensity ultrasound was approved by the United States Food and Drug Administration (FDA) for the treatment of uterine fibroids. It has since been utilized in conditions including benign prostate hyperplasia and several solid-organ malignancies, and subsequently modified for lipolysis. ${ }^{2-5}$ High-intensity focused ultrasound (HIFU) creates bulk heating of targeted tissue by inducing local tissue cavitation. By decreasing the pulse duration $(<150 \mathrm{~ms}$ ), increasing the frequency, and decreasing the energy emitted, this concept can be applied with greater precision for noninvasive facial skin tightening. In 2009, microfocused ultrasound (MFUS), also referred to as intense
ISSN 0736-6825. 
focused ultrasound (IFUS) (Ulthera, Mesa, AZ) became FDA approved for brow lift, followed by neck and chin lift in 2012, and subsequently treatment of lines and wrinkles of the décolletage in 2014. In comparison to HIFU, which emits energies of approximately $100 \mathrm{~J}$ and frequencies in the kilohertz range, MFUS delivers shorter pulses of lower energies $(0.18-1.2 \mathrm{~J})$ with greater frequencies delivered in the megahertz range. 6

\section{Microfocused Ultrasound}

The mechanism of action of MFUS is predicated on its delivery of acoustic energy, which generates vibration in the targeted tissue causing molecular friction. Some of this mechanical energy is converted into thermal energy, generating heat in excess of $60^{\circ} \mathrm{C}$, the approximate temperature required to denature collagen and induce neocollagenesis. ${ }^{7}$ Subsequently, there is coagulative necrosis, which manifests histologically as discrete, small ( $\sim 1 \mathrm{~mm}^{3}$ ) thermal injury zones (TIZs) in the reticular dermis and subdermis, with well-defined and sharply marginated borders of unaffected tissue. ${ }^{8-10}$

The nonspecific heating of tissue denatures collagen, presumably by breaking the hydrogen bonds that create the triple helix. Collagen fibrils subsequently become thicker and shorter, with greater tensile strength, resulting in decreased skin laxity. ${ }^{11,12}$ Furthermore, the microscopic TIZs create a local wound healing milieu with normalization of the type I to type III collagen ratio.

In contrast to other noninvasive tissue-tightening modalities, MFUS targets deeper into the dermis and superficial musculoaponeurotic system (SMAS). ${ }^{5}$ The SMAS is composed of collagen and elastic fibers, encasing muscles of facial expression and attaches to the dermis. It is an attractive target due to its viscoelastic properties and reduced stress relaxation effect when compared with the skin alone. ${ }^{13}$ This phenomenon is defined as the decrease in the tensile strength of a tissue after the tissue is stretched.

The Ulthera device is coupled to a high-resolution imaging ultrasound, which allows for visualization of the targeted tissue to a depth of $8 \mathrm{~mm}$. The Ulthera technology can be applied using one of four transducers to target the SMAS (4.5 mm $4 \mathrm{MHz}$ or $7 \mathrm{MHz}$ ), deep dermis ( $3 \mathrm{~mm} 7 \mathrm{MHz}$ ), or the dermis $(1.5 \mathrm{~mm} 10 \mathrm{MHz})$. Given the inverse relationship between wavelength and penetrance, the 4-MHz handpiece, for example, will provide greater thermal injury depth than the 7-MHz transducer. Thus, by utilizing the 4-MHz transducer at $4.5 \mathrm{~mm}$, the TIZ at the fibromuscular layer is of same potency and energy for the entire vertical length of the coagulation point, like a cylinder. Using the 7-MHz transducer, the TIZ is shaped like an inverted cone, with a wider injury created more superficially tapering at the base. The 3.0- and 1.5-mm transducers target the reticular dermis, allowing for more superficial treatments that can be employed on more sensitive locations with thinner skin such as the forehead and temples. ${ }^{1}$ It is important to note that although treating with lower energies will result in a slightly smaller volume TIZ, the temperature delivered is not altered. ${ }^{14} \mathrm{~A}$ review of the published literature regarding MFUS can be found in -Table 1.

Histologically, the coagulated TIZ appears in the shape of a vertical inverted cone. As the exposure time is increased, the larger the TIZ propagates in an axial direction; furthermore, there is a greater risk of bulk heating of the tissue. ${ }^{6}$ Because Ultherapy is targeted to a specific tissue depth instead of a particular chromophore, the risk of postinflammatory pigment alteration, a common complication of laser therapies in darker skin types, is significantly minimized. Moreover, because MFUS creates a sharp focus millimeters beneath the epidermis, there is negligible epidermal thermal energy absorption, thereby obviating the need for skin cooling. Even utilizing the most powerful transducer ( $4 \mathrm{MHz}$ ), only $1.2 \mathrm{~J}$ is delivered to the tissue at $4.5-\mathrm{mm}$ depth. ${ }^{1}$

\section{Patient Selection}

As with any tissue-tightening procedure, patient selection and establishing realistic expectations are essential components of the treatment process. Although noninvasive modalities have gained popularity, the gold standard for treating facial skin laxity remains surgical intervention. A patient with mild-to-moderate skin laxity is a superior candidate for MFUS versus one categorized as moderate to severe, a better surgical candidate ( $\mathbf{- F i g . 1}$ ). In addition, because the procedure is dependent on a patient's wound healing response, factors such as age, dermatoheliosis, and smoking may adversely affect the collagen remodeling. Furthermore, a body mass index of less than 30 has been associated with a more impressive clinical response. ${ }^{15}$ Thus, it is imperative when discussing noninvasive modalities such as MFUS to create realistic expectations of modest improvement of skin laxity and rhytides.

In our clinical experience, younger patients tend to enjoy better results from MFUS treatment alone because they tend to have better structural support (i.e., fat and bone) for their skin to reposition onto, and they have less laxity to improve. However, in a retrospective study performed by one of the authors (S.G.F.), patients older than 60 years were just as likely to achieve a significant improvement in their laxity as patients younger than 60 years; this is not to say they achieved a taut jawline, but they did have significant improvement from their baseline. ${ }^{28}$ Additional populations merit mention. Patients who have had surgical rhytidectomy and wish to delay or prevent a repeat operation can benefit from MFUS. There is a subset of patients, predominately women, with minimal to no laxity who are interested in the so-called pre-juvenation, and do well with MFUS. In contrast, male patients tend to present later with moderate-to-severe facial skin laxity when they are perhaps better surgical candidates.

Contraindications to MFUS include active infection, open wounds at the treatment site, cystic acne, and pregnancy. Relative contraindications include treating directly over keloids, implants, and fillers, or any individual with impaired wound healing. 5 
Table 1 Clinical studies evaluating microfocused ultrasound with visualization

\begin{tabular}{|c|c|c|c|}
\hline Author (year) & Article & Treated areas & Result \\
\hline $\begin{array}{l}\text { Gliklich et al } \\
(2007)\end{array}$ & $\begin{array}{l}\text { Clinical pilot study of intense } \\
\text { ultrasound therapy to deep } \\
\text { dermal facial skin and } \\
\text { subcutaneous tissues }\end{array}$ & Face and neck & $\begin{array}{l}\text { TIZ were consistent in size and depth. } \\
\text { Increasing power did not alter depth of } \\
\text { center of TIZ }\end{array}$ \\
\hline $\begin{array}{l}\text { White et al } \\
\text { (2007) }\end{array}$ & $\begin{array}{l}\text { Selective transcutaneous delivery } \\
\text { of energy to porcine soft tissues } \\
\text { using intense ultrasound (IUS) })^{8}\end{array}$ & Ex vivo porcine tissue & $\begin{array}{l}\text { Consistent TIZ created without epidermal } \\
\text { disruption detected by ultrasound imaging }\end{array}$ \\
\hline Alam et al (2010) & $\begin{array}{l}\text { Ultrasound tightening of facial and } \\
\text { neck skin: a rater-blinded } \\
\text { prospective cohort study }\end{array}$ & $\begin{array}{l}\text { Forehead, neck, temples, } \\
\text { cheeks, preauricular and } \\
\text { submental areas }\end{array}$ & $\begin{array}{l}\text { Objective assessment at } 90 \text { days: } \\
86 \%(30 / 35) \text { experienced clinically } \\
\text { significant eyebrow lift } \\
\text { Average brow height elevations of } 1.7 \mathrm{~mm}\end{array}$ \\
\hline Lee et al (2012) & $\begin{array}{l}\text { Multiple pass ultrasound tighten- } \\
\text { ing of skin laxity of the lower face } \\
\text { and neck }\end{array}$ & Lower face, neck & $\begin{array}{l}\text { Objective assessment at } 90 \mathrm{~d}: 90 \%(9 / 10) \\
\text { improvement } \\
\text { Patient assessment at } 90 \mathrm{~d}: 80 \%(8 / 10) \\
\text { improvement }\end{array}$ \\
\hline Suh et al (2011) & $\begin{array}{l}\text { Intense focused ultrasound } \\
\text { tightening in Asian skin: clinical } \\
\text { and pathologic results }\end{array}$ & $\begin{array}{l}\text { Forehead, temple, cheeks, } \\
\text { submentum }\end{array}$ & $\begin{array}{l}\text { Objective assessment at } 2 \text { mo: } 91 \%(20 / 22) \\
\text { much improved nasolabial fold/jawline } \\
9 \%(2 / 22) \text { mildly improved nasolabial fold/ } \\
\text { jawline } \\
\text { Patient assessment at } 2 \text { mo: } \\
\text { Nasolabial folds: } 77 \%(17 / 22) \text { much } \\
\text { improved, } 23 \% \text { mildly improved } \\
\text { Jawline } 73 \%(16 / 22) \text { much improved, } 27 \% \\
\text { mildly improved } \\
\text { Histology: mean dermal thickness at } 2 \text { mo: } \\
\text { Before treatment: } 1.32 \pm 0.18 \mathrm{~mm} \\
\text { After treatment: } 1.63 \pm 0.31 \mathrm{~mm} \\
23.7 \% \text { increased collagen in reticular dermis }\end{array}$ \\
\hline \multirow[t]{2}{*}{$\begin{array}{l}\text { Sasaki and Tevez } \\
\text { (2012) }\end{array}$} & \multirow[t]{2}{*}{$\begin{array}{l}\text { Clinical efficacy and safety of } \\
\text { focused-image ultrasonography: } \\
\text { a } 2 \text {-year experience }\end{array}$} & \multirow[t]{2}{*}{ Brow, marionette lines } & $\begin{array}{l}\text { Study 1: } 6 \text { mo after treatment, brows and } \\
\text { marionette lines that received vertical } \\
\text { treatment revealed higher lifting compared } \\
\text { with contralateral side treated with } \\
\text { horizontal treatment lines }\end{array}$ \\
\hline & & & $\begin{array}{l}\text { Study 2: } 6 \text { mo after treatment, brow and } \\
\text { marionette lines treated with higher energy } \\
\text { and multiple passes received greater lifting } \\
\text { compared with those tread with fewer } \\
\text { passes and lower energies. No significant } \\
\text { side effects noted }\end{array}$ \\
\hline Suh et al (2012) & $\begin{array}{l}\text { An intense-focused ultrasound } \\
\text { tightening for the treatment of } \\
\text { infraorbital laxity }{ }^{33}\end{array}$ & $\begin{array}{l}\text { Lower eyelid (1-2 } \\
\text { treatments) }\end{array}$ & $\begin{array}{l}6 \text { mo after one to two treatment sessions: } \\
\text { Mean objective improvement (quartile } \\
\text { grading scale): } 2.20 \pm 0.46 \\
13.33 \%(2 / 15)-\text { much improved } \\
73.33 \%(11 / 15) \text {-improved } 13.33 \%(2 / 15)- \\
\text { unchanged } \\
\text { Mean subjective improvement score: } \\
2.20 \pm 0.41 \\
20.00 \%(3 / 15)-\text { much improved } \\
80.00 \%(12 / 15) \text {-improved }\end{array}$ \\
\hline Fabi et al (2013) & $\begin{array}{l}\text { Evaluation of microfocused } \\
\text { ultrasound with visualization for } \\
\text { lifting, tightening, and wrinkle } \\
\text { reduction of the décolletage }{ }^{24}\end{array}$ & Décolletage & $\begin{array}{l}\text { 1-2 point Improvement at } 90 \mathrm{~d}: 46 \% \\
1-2 \text { point improvement at } 180 \mathrm{~d}: 62 \% \\
\text { Mean mid-clavicular to nipple distance } \\
\text { decreased from } 20.9 \text { to } 19.5 \mathrm{~cm} \text { at } 180 \mathrm{~d}\end{array}$ \\
\hline $\begin{array}{l}\text { Casabona and } \\
\text { Michalany } \\
(2014)\end{array}$ & $\begin{array}{l}\text { Microfocused ultrasound with } \\
\text { visualization and fillers for } \\
\text { increased neocollagenesis: clinical } \\
\text { and histological evaluation }{ }^{25}\end{array}$ & Thigh & $\begin{array}{l}\text { Dermal filler (either hyaluronic acid or } \\
\text { calcium hydroxyapatite) followed by MFU } \\
\text { was found to be safe without granuloma or } \\
\text { alteration of the filler appearance } \\
\text { histologically or efficacy when injected into } \\
\text { thigh of a single patient } 6 \text { mo after } \\
\text { treatment }\end{array}$ \\
\hline
\end{tabular}


Table 1 (Continued)

\begin{tabular}{|c|c|c|c|}
\hline Author (year) & Article & Treated areas & Result \\
\hline $\begin{array}{l}\text { Woodward et al } \\
\text { (2014) }\end{array}$ & $\begin{array}{l}\text { Safety and efficacy of combining } \\
\text { microfocused ultrasound with } \\
\text { fractional } \mathrm{CO}_{2} \text { laser resurfacing for } \\
\text { lifting and tightening the face and } \\
\text { neck }\end{array}$ & Full face and neck & $\begin{array}{l}\text { Greater improvement of facial rhytides and } \\
\text { skin laxity with combination MFU + AFL } \\
\text { compared with either modality alone. } \\
\text { Safety profile similar to that of AFL alone }\end{array}$ \\
\hline $\begin{array}{l}\text { Sabet-Peyman } \\
\text { and Woodward } \\
(2014)\end{array}$ & $\begin{array}{l}\text { Complications using intense } \\
\text { ultrasound therapy to treat deep } \\
\text { dermal facial skin and subcutane- } \\
\text { ous tissues }\end{array}$ & Full face and neck & $\begin{array}{l}23 \%(9 / 39) \text { of patients had complications } \\
\text { including mandibular ecchymosis, facial } \\
\text { edema, transient lip and brow paralysis, and } \\
\text { pseudofacial fat atrophy }\end{array}$ \\
\hline Fabi et al (2014) & $\begin{array}{l}\text { Retrospective evaluation of micro- } \\
\text { focused ultrasound lifting and } \\
\text { tightening } 28\end{array}$ & Full face and neck & $\begin{array}{l}\text { Physician Global Aesthetic Improvement } \\
\text { Scale: } 81.3 \% \text { (at } 90 \mathrm{~d} \text { ) and } 77.7 \% \text { (at } 180 \mathrm{~d} \text { ) of } \\
\text { patients achieved improvement } \\
\text { Subjective Global aesthetic Improvement } \\
\text { Scale } 75 \% \text { (at } 90 \mathrm{~d} \text { ) and } 77.8 \% \text { (at } 180 \mathrm{~d} \text { ) of } \\
\text { patients achieved improvement } \\
\text { Blinded reviewer assessment: } 67 \% \text { of } \\
\text { patients achieved improvement }\end{array}$ \\
\hline Lee et al (2015) & $\begin{array}{l}\text { The efficacy and safety of intense } \\
\text { focused ultrasound in the treat- } \\
\text { ment of enlarged pores in Asian } \\
\text { skin }{ }^{11}\end{array}$ & $\begin{array}{l}\text { Split face with } 1.5 \text { or } 3.0 \mathrm{~mm} \\
\text { transducer } \\
\text { Full face, lower face, or up- } \\
\text { per face }\end{array}$ & $\begin{array}{l}\text { Physician subjective improvement: clinical } \\
\text { pore improvements in } 86 \text { and } 91 \% \text { pore } \\
\text { improvement status post } 1.5-\text { and } 3.0-\mathrm{mm} \\
\text { transducer treatment, respectively. Mean } \\
\text { improvement scores: } 1.7 \text { and } 1.9 \text { for } 1.5 \text { - and } \\
\text { 3.0-mm transducer, respectively }\end{array}$ \\
\hline Oni et al (2014) & $\begin{array}{l}\text { Evaluation of a microfocused ul- } \\
\text { trasound system for improving } \\
\text { skin laxity and tightening in the } \\
\text { lower face }\end{array}$ & Lower face and neck & $\begin{array}{l}\text { Subjective assessment } 90 \mathrm{~d} \text { : skin laxity } \\
\text { improvement of cheeks in } 63.6 \%(59 / 93) \text { of } \\
\text { patients } \\
\text { Greater improvement in patients with BMI } \\
>30 \mathrm{~kg} / \mathrm{m}^{2}\end{array}$ \\
\hline Pak et al (2014) & $\begin{array}{l}\text { Safety and efficacy of Ulthera in } \\
\text { the rejuvenation of aging lower } \\
\text { eyelids: a pivotal clinical trial }\end{array}$ & Lower eyelids & $\begin{array}{l}\text { Using CT imaging to compare pre- and } \\
\text { postprocedure distances from the inferior } \\
\text { point of the supraorbital right and superior } \\
\text { most point of the infraorbital rim, there was } \\
\text { a } 0.51 \pm 0.23 \mathrm{~mm} \text { difference in right eye } \\
\text { and } 0.54 \pm 0.17 \mathrm{~mm} \text { in left eye at } 12 \mathrm{wk} \\
\text { Subject Patient Satisfaction Score: } \\
3.85 \pm 0.69 \\
\text { Objective Satisfaction Score: } 3.45 \pm 0.69 \\
\text { (blinded observer 1) and } 3.25 \pm 1.43 \\
\text { (blinded observer } 2 \text { ) }\end{array}$ \\
\hline Suh et al (2015) & $\begin{array}{l}\text { Intense focused ultrasound for } \\
\text { facial tightening: histologic } \\
\text { changes in } 11 \text { patients } 30\end{array}$ & Full face & $\begin{array}{l}\text { Objective assessment at } 2 \text { mo: } 63.6 \%(7 / 11) \\
\text { improvement } \\
\text { Subjective assessment at } 2 \text { mo: } 54.5 \%(6 / 11) \\
\text { improvement } \\
\text { Histologic analysis at } 2 \text { mo: increased and } \\
\text { thickened collagen in reticular dermis }\end{array}$ \\
\hline Suh et al (2015) & $\begin{array}{l}\text { Comparative histometric analysis } \\
\text { of the effects of high-intensity } \\
\text { focused ultrasound and } \\
\text { radiofrequency on skin }\end{array}$ & Cheek & $\begin{array}{l}\text { Monopolar RF causes neocollagenesis in the } \\
\text { papillary dermis, upper, mid, deep reticular } \\
\text { dermis } \\
\text { Monopolar RF causes neoelastogenesis in } \\
\text { the papillary dermis; upper, mid reticular } \\
\text { dermis } \\
\text { MFUS causes neocollagenesis and neoelas- } \\
\text { togenesis in the deep reticular dermis }\end{array}$ \\
\hline
\end{tabular}

\section{Pain Management}

According to the literature, discomfort associated with this procedure appears quite variable. In October 2012, Ulthera altered their software and treatment recommendations to mitigate this discomfort. ${ }^{16}$ These changes included treating with lower energy levels with increased number of treatment lines. Studies to quantify the pain associated with the proce- dure have yielded inconsistent results, 1.93/10 on a visual analog scale with the use of topical anesthetic cream and another study published in 2011 in which 54\% of patients rated their pain as severe after a single pass treatment without any topical anesthetic. ${ }^{17}$ This could be attributed to the lack of topical anesthetic, as well as the latter study being performed prior to protocol alteration. Sasaki and Tevez found that treatment of the eyebrow and periorbital 


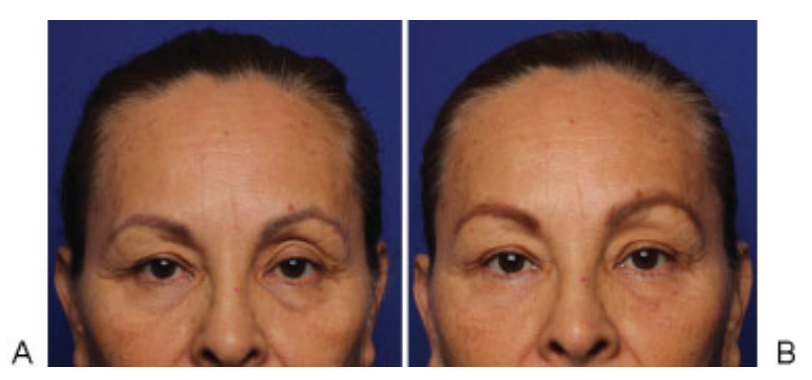

Fig. 1 (A) Ulthera brow before treatment. (B) Ulthera brow 3 months after one treatment.

area was associated with greater pain (5.7 out of 10 ) than that of the face (3.7 out of 10) and neck (3.6 out of 10). ${ }^{18}$ Clinical experience has revealed the submental and submandibular areas to be more sensitive to therapy than cheeks, likely secondary to the proximity to underlying bony prominences and to less tissue thickness. ${ }^{19}$

In a study by Alam et al, the pain scale was noted to be $3 / 10$ to $4 / 10$ on a visual analog scale; however, 5 of the 35 patients noted pain levels of $7 / 10$ or greater. These individuals were unique in that they were naive to other cosmetic procedures, including laser, light, radiofrequency, or chemical peels, perhaps contributing to their sensitivity scores. ${ }^{9}$ However, a subsequent 2014 study of 10 patients by Kakar et al found no significant difference in pain ratings for naive and non-naive individuals with multiple devices, including MFUS. ${ }^{20}$

To attempt to minimize potential discomfort, a wide variety of methods have been employed, such as NSAIDs, acetaminophen, topical anesthesia, oral anxiolytics and narcotics, nerve blocks, and local anesthesia, as well as conscious sedation. In our experience, a combination of 30\% topical lidocaine along with oral ibuprofen or intramuscular ketorolac 45 to 60 minutes prior to the procedure generally renders it well tolerated. Stretching the skin during treatment and a handheld massager can also help enhance comfort ( - Fig. 2). For especially sensitive patients, we offer the option of diazepam and/or Percocet (oxycodone/acetaminophen), provided they are not driving after the procedure, or oral diazepam (5-10 mg) and an intramuscular injection of 50 to $100 \mathrm{mg}$ of meperidine and $50 \mathrm{mg}$ of hydroxyzine 30 minutes prior to treatment.

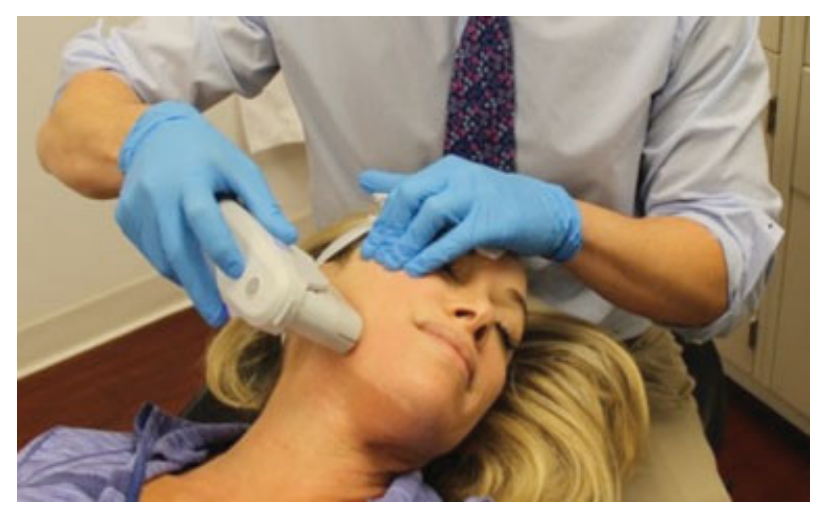

Fig. 2 Treatment technique: pulling the skin upward while treating the cheek enhances patient comfort.
Table 2 Treatment parameters

\begin{tabular}{|l|l|}
\hline Treatment areas & Transducers \\
\hline Periorbital & $4.5 \mathrm{~mm}(7 \mathrm{MHz}, 0.75-1.05 \mathrm{~J})$ \\
& $3.0 \mathrm{~mm}(0.3-0.45 \mathrm{~J})$ \\
& $1.5 \mathrm{~mm}(0.18-0.25 \mathrm{~J})$ \\
\hline Cheeks and upper neck & $4.5 \mathrm{~mm}(4 \mathrm{MHz}, 0.90-1.2 \mathrm{~J})$ \\
& $3.0 \mathrm{~mm}(0.3-0.45 \mathrm{~J})$ \\
\hline
\end{tabular}

\section{Procedure}

After cleaning the skin, the treatment areas are defined; these areas traditionally include the cheek, periorbit, brow, and neck and could include off face sites such as the décolletage and skin above the knees, lateral buttocks, posterior arms/ elbows, inner thighs, and abdomen. The treatment area is then outlined with a planning card to establish the number of treatment lines required. After applying a thin layer of ultrasound gel, the transducer is placed perpendicularly and firmly to the skin. Correct coupling of the transducer is verified using the real-time ultrasound imaging. Treatment lines are placed at approximately 3-mm intervals in a linear distribution. Treatment is typically performed at two depths, one pass of the $4.5-\mathrm{mm}$ transducer followed by one pass with the $3.0-\mathrm{mm}$ superficial transducer. In thinner tissues, such as the periorbital region, similar layering may be accomplished with the 3.0- and 1.5-mm transducers (- Table 2). The 4-MHz 4.5-mm transducer is usually used on the neck and cheeks, while the 7-MHz 3.0-mm transducer is commonly applied to the upper face. Treatment should be avoided over the thyroid and the orbital cavity. After the procedure, the ultrasound gel should be removed and an emollient applied.

\section{Side Effects}

One of the decisive advantages of MFUS is its noninvasive nature. The safety profile of MFUS has been well established both in the literature and clinical practice. However, while most of the documented side effects are transient in nature, this procedure is not without risks.

Postprocedure erythema, edema, ecchymosis, transient paralysis, pain, and postinflammatory pigment alterations have all been described in the literature. While evaluating the over 18 published peer-reviewed journal articles assessing the safety profile, Hitchcock et al found that in the 307 patients who received MFUS to facial skin, the most commonly experienced side effects were transient erythema lasting beyond 1 hour and up to 24 hours (7) and edema lasting up to three days (6). ${ }^{32}$ Less commonly reported adverse events included bruising, numbness, welts, and striations; striations were attributed to improper coupling of the transducer to the skin. Other adverse events were also transient, including postinflammatory hyperpigmentation in two patients, presumably secondary to improper coupling of the 4.5-mm transducer when treating the forehead with insufficient tissue depth, and one marginal mandibular nerve paresis. The latter complication can be avoided by 
understanding the course of the marginal mandibular nerve, forward below the angle of the mandible, beneath the platysma until it crosses up, and forward over the body of the mandible to innervate the muscles of the lower lip. In Ultherasponsored clinical trials assessing 769 patients treated with MFUS, $0.2 \%$ of patients experienced adverse events, all of which were transient, including pain (2), nerve irritation (2), numbness/paresthesia (2), lumps (1), erythema (1), tingling (1), swelling (2), headache (2), rash (1), and pruritus (2). ${ }^{21}$

\section{Multimodality Approach}

To date, most of the studies on MFUS have assessed the efficacy and safety of MFUS intervention alone; however, in clinical practice, there is often a multimodality approach employed to create an additive effect. Although studies are lacking, Friedmann found that combination treatment with intense pulsed light (IPL), MFUS, and poly-L-lactic acid (PLLA) is safe and effective. ${ }^{14}$ This approach targeting photodamage (IPL), skin laxity (MFUS), and volume depletion (PLLA) is aimed at targeting multiple components of aging to produce an augmented effect. When employing this combination, the authors recommend first treating with IPL, followed by MFUS and PLLA. Because resultant erythema and inflammation from MFUS could lead to greater energy absorption from the IPL (and thus side effects), the authors perform IPL first. To avoid blood contamination of the IPL crystal or MFUS transducer, they inject PLLA last. When employing this combination treatment, the authors recommend waiting 2 weeks for PLLA injection to allow associated swelling to subside. Although there is theoretic risk of an inflammatory site reaction when combining IPL and PLLA, in a retrospective study of 90 patients, Fabi and Goldman found no significant increase in side effects after 1.63 treatments of IPL and PLLA. ${ }^{33}$ The author (S.G.F.) employs the same combination of IPL, MFUS, and PLLA to optimize photorejuvenation of the chest because of the potential synergy that may result from all three treatments on the same day.

Recently two of the authors (S.G.F. and J.B.G.) presented a retrospective chart review of 101 patients treated with MFUS and complimentary neurotoxins and/or fillers within 6month proximity to assess safety. ${ }^{34}$ of 98 patients who received fillers within a 6-month period of MFUS, 16 had their treatment the same day as MFUS, and 4 of 20 patients with incobotulinum toxin A had their treatment the same day as MFUS. Seven out of 101 patients experienced adverse events, including purpura, paresthesias, edema, and herpes simplex outbreak, 4 of which resolved, the other 3 were lost to follow-up. This review supported the safety of combining MFUS and fillers/neurotoxins, though caution is advised with same-day treatments.

Although off-label, Kornstein described Ulthera's potential utility in correcting silicone lip deformity in a single individual. Because MFUS creates TIZs, the postulated mechanism of action is via scar remodeling. Although no further cases have been reported, further evaluation is warranted to assess the value of MFUS in this context. ${ }^{35}$

\section{Summary}

MFUS offers an attractive option to physicians in the arsenal of noninvasive facial-tightening devices. By creating TIZ in the dermis and subcutis and sparing the epidermis, this novel technology is safe. Although MFUS creates histologically evident, reproducible energy delivery, the clinical results can be variable, particularly in those with greater skin laxity and body mass index.

With a greater spectrum of devices, injectables, and topical agents on the market, combination therapy is likely the optimal approach to target the various components associated with facial photoaging. The safety profile of MFUS has been well established; with proper technique on an appropriate patient population, adverse events can be minimized. Further studies to further elucidate optimal patient retreatment times, establish efficacy and safety of combination therapies, and investigate potential future applications of MFUS are warranted. With clinically significant results, patient satisfaction, and an attractive side-effect profile, MFUS provides an excellent choice for a patient with minimal-to-moderate skin laxity, in whom surgical intervention is not desired and/or warranted.

\section{References}

1 Brobst RW, Ferguson M, Perkins SW. Ulthera: initial and six month results. Facial Plast Surg Clin North Am 2012;20(2):163-176, vi

2 Jolesz FA. MRI-guided focused ultrasound surgery. Annu Rev Med 2009;60:417-430

3 Jolesz FA, McDannold N. Current status and future potential of MRI-guided focused ultrasound surgery. J Magn Reson Imaging 2008;27(2):391-399

4 Jenne JW, Rastert R, Rademaker G, Divkovic G, Debus J, Huber PE. MRI-guided surgery with high intensity focused ultrasound [in German]. Z Med Phys 2003;13(3):193-197

5 MacGregor JL, Tanzi EL. Microfocused ultrasound for skin tightening. Semin Cutan Med Surg 2013;32(1):18-25

6 Laubach HJ, Makin IR, Barthe PG, Slayton MH, Manstein D. Intense focused ultrasound: evaluation of a new treatment modality for precise microcoagulation within the skin. Dermatol Surg 2008; 34(5):727-734

7 Bozec L, Odlyha M. Thermal denaturation studies of collagen by microthermal analysis and atomic force microscopy. Biophys J 2011;101(1):228-236

8 White WM, Makin IR, Barthe PG, Slayton MH, Gliklich RE. Selective creation of thermal injury zones in the superficial musculoaponeurotic system using intense ultrasound therapy: a new target for noninvasive facial rejuvenation. Arch Facial Plast Surg 2007; $9(1): 22-29$

9 Alam M, White LE, Martin N, Witherspoon J, Yoo S, West DP. Ultrasound tightening of facial and neck skin: a rater-blinded prospective cohort study. J Am Acad Dermatol 2010;62(2): 262-269

10 Minkis K, Alam M. Ultrasound skin tightening. Dermatol Clin 2014;32(1):71-77

11 Lee HJ, Lee KR, Park JY, Yoon MS, Lee SE. The efficacy and safety of intense focused ultrasound in the treatment of enlarged facial pores in Asian skin. J Dermatolog Treat 2015;26(1):73-77

12 Lee HS, Jang WS, Cha YJ, et al. Multiple pass ultrasound tightening of skin laxity of the lower face and neck. Dermatol Surg 2012; 38(1):20-27 
13 Har-Shai Y, Bodner SR, Egozy-Golan D, et al. Viscoelastic properties of the superficial musculoaponeurotic system (SMAS): a microscopic and mechanical study. Aesthetic Plast Surg 1997;21(4): 219-224

14 Friedmann DP. Comments on "evaluation of a microfocused ultrasound system for improving skin laxity and tightening in the lower face". Aesthet Surg J 2015;35(3):NP81-NP82

15 Oni G, Kenkel JM. Response to "comments on "evaluation of a microfocused ultrasound system for improving skin laxity and tightening in the lower face'”. Aesthet Surg J 2015;35(3): NP83-NP84

16 Pritzker RN, Hamilton HK, Dover JS. Comparison of different technologies for noninvasive skin tightening. J Cosmet Dermatol 2014;13(4):315-323

17 Chan NP, Shek SY, Yu CS, Ho SG, Yeung CK, Chan HH. Safety study of transcutaneous focused ultrasound for non-invasive skin tightening in Asians. Lasers Surg Med 2011;43(5):366-375

18 Sasaki GH, Tevez A. Clinical efficacy and safety of focused-image ultrasonography: a 2-year experience. Aesthet Surg J 2012;32(5): 601-612

19 Oni G, Hoxworth R, Teotia S, Brown S, Kenkel JM. Evaluation of a microfocused ultrasound system for improving skin laxity and tightening in the lower face. Aesthet Surg J 2014;34(7): 1099-1110

20 Kakar R, Ibrahim O, Disphanurat W, et al. Pain in naïve and nonnaïve subjects undergoing nonablative skin tightening dermatologic procedures: a nested randomized control trial. Dermatol Surg 2014;40(4):398-404

21 Gliklich RE, White WM, Slayton MH, Barthe PG, Makin IR. Clinical pilot study of intense ultrasound therapy to deep dermal facial skin and subcutaneous tissues. Arch Facial Plast Surg 2007;9(2): 88-95

22 Suh DH, Shin MK, Lee SJ, et al. Intense focused ultrasound tightening in Asian skin: clinical and pathologic results. Dermatol Surg 2011;37(11):1595-1602

23 Suh DH, Oh YJ, Lee SJ, et al. An intense-focused ultrasound tightening for the treatment of infraorbital laxity. J Cosmet Laser Ther 2012;14(6):290-295

24 Fabi SG, Massaki A, Eimpunth S, Pogoda J, Goldman MP. Evaluation of microfocused ultrasound with visualization for lifting, tighten- ing, and wrinkle reduction of the décolletage. J Am Acad Dermatol 2013;69(6):965-971

25 Casabona G, Michalany N. Microfocused ultrasound with visualization and fillers for increased neocollagenesis: clinical and histological evaluation. Dermatol Surg 2014;40(Suppl 12): S194-S198

26 Woodward JA, Fabi SG, Alster T, Colón-Acevedo B. Safety and efficacy of combining microfocused ultrasound with fractional CO2 laser resurfacing for lifting and tightening the face and neck Dermatol Surg 2014;40(Suppl 12):S190-S193

27 Sabet-Peyman EJ, Woodward JA. Complications using intense ultrasound therapy to treat deep dermal facial skin and subcutaneous tissues. Dermatol Surg 2014;40(10):1108-1112

28 Fabi SG, Goldman MP. Retrospective evaluation of micro-focused ultrasound for lifting and tightening the face and neck. Dermatol Surg 2014;40(5):569-575

29 Pak CS, Lee YK, Jeong JH, Kim JH, Seo JD, Heo CY. Safety and efficacy of Ulthera in the rejuvenation of aging lower eyelids: a pivotal clinical trial. Aesthetic Plast Surg 2014;38(5):861-868

30 Suh DH, So BJ, Lee SJ, Song KY, Ryu HJ. Intense focused ultrasound for facial tightening: histologic changes in 11 Patients. J Cosmet Laser Ther 2015;17(4):200-203

31 Suh DH, Choi JH, Lee SJ, Jeong KH, Song KY, Shin MK. Comparative histometric analysis of the effects of high-intensity focused ultrasound and radiofrequency on skin. J Cosmet Laser Ther 2015; 17(5):230-236

32 Hitchcock TM, Dobke MK. Review of the safety profile for microfocused ultrasound with visualization. J Cosmet Dermatol 2014; 13(4):329-335

33 Fabi SG, Goldman MP. The safety and efficacy of combining poly-Llactic acid with intense pulsed light in facial rejuvenation: a retrospective study of 90 patients. Dermatol Surg 2012;38(7, Pt 2): 1208-1216

34 Fabi SG, Green JB, Werschler WP, Mills DC, Weiss R. Retrospective safety study of combining micro-focused ultrasound with visualization (MFU-V) with neurotoxin and fillers (HA and CaHA). Presented at: American Academy of Dermatology meeting; March 4-8, 2016; Washington, DC

35 Kornstein AN. Ulthera for silicone lip correction. Plast Reconstr Surg 2012;129(6):1014e-1015e 